\title{
DEVELOPING HYPERNORMS FOR CORPORATE CODES OF ETHICS
}

\author{
Timo HEROLD \\ Christopher STEHR \\ Karlshochschule International University, Germany
}

\begin{abstract}
With regard to the economic globalization, there are no obligatory rules at the global level. The problem for a company is determining which norms and values the company should follow. Should it comply with norms of the country of origin or with norms of the host country?

In this paper, norms will be developed and justified. For this reason, international regulations such as the human rights or the labor standards of the International Labor Organization (ILO) will be consulted. Norms for global corporate ethics will be derived from these codes. To verify and falsify respectively the established norms, the method of expert interviews is used. The interview partners are experts in the fields of religion, culture and persons from non-governmental organizations and company representatives.
\end{abstract}

Keywords: Business ethics, Code of ethics, Hypernorm, International standards, Multinational corporations

\section{INTRODUCTION}

Business ethics has become a focus of corporate management's attention in recent years. This is caused on the one hand by public pressure and on the other hand by a change of the strategy of the companies to respond to this pressure (Usrey, 2007). Both were activated by a public notice of scandals, like corruption or a violation of working or environmental standards (Zelizer, 2007 and Boatright, 2007). In light of such incidents, companies are compelled to deal with ethical questions just in the same way they do with their well-known business strategic questions (Déniz-Déniz, Garcia-Falcón, 2002).

In times of economic and entrepreneurial globalization, companies do not act nationally but internationally or globally. Thus, an adjustment of the corporate ethics to an international or global framework is necessary.

The globalization of companies is a challenge for corporate ethics. There are no compulsory laws at the global level because of an asymmetric development of the political and economical processes of globalization (Stiglitz, 2006). The companies cannot align their behavior to a global valid framework of norms and laws (Chan, 2007). There are no obligatory rules on global level to which a company could comply. Only some rudiments like the OECD guidelines for multinational corporations exist.

On the other side, national legislation is losing its influence on companies. IF a company is acting on global level it is possible for the company to choose the system of laws which are best for the company.

The managers of these firms have to decide to which norms and values they want to conform in their daily work (Aßländer, Brink, 2008). This decision meets the areas of external legitimating of the companies behavior and the internal coordination of the employee's behavior. Figure 1 shows that the deficient international law and the loss of influence of national law lead to the necessity of a voluntary self-commitment. 


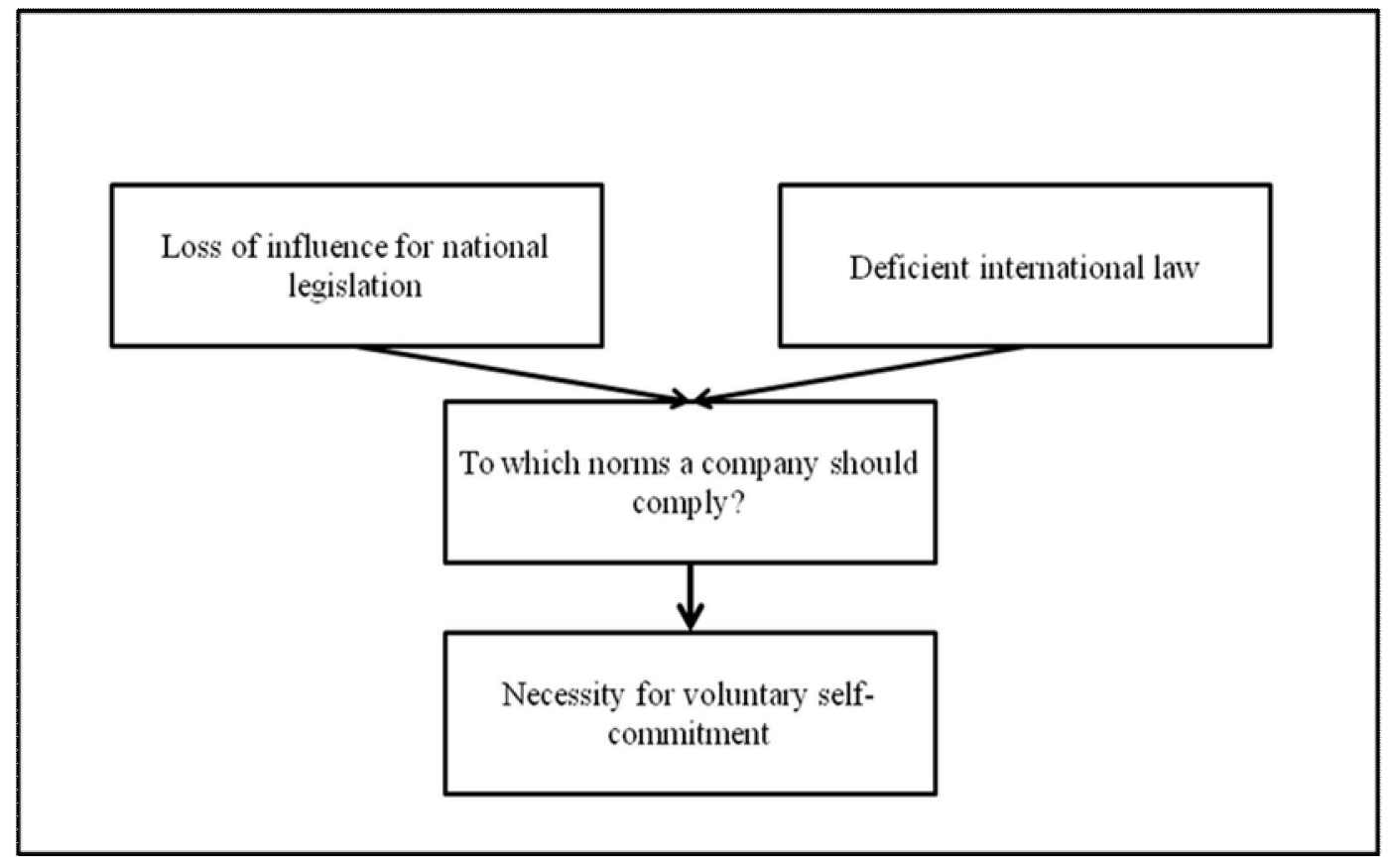

\section{Figure 1: Necessity for voluntary self-commitment (own drawing)}

Developing norms for a corporate code of ethics is the central goal of this research. These norms should take the challenges of entrepreneurial globalization into account. They should be applicable at the global level for companies. Do such norms exist? This is one of the central questions of this research.

In theory, such norms are called hypernorms. To find such hypernorms for business is necessary to develop a global code of ethics for companies. Linked to this are the questions,: what are hypernorms and how can they be identified?

Based upon the theory of hypernorms by Thomas Donaldson and Thomas Dunfee (1999) this article presents a process for developing such norms. In the following step the process is used to point out hypernorms.

In a further step this article shows a code of ethics consisting of the norms which are derived from the process. This code of ethics can be a base for international or global companies to develop their own code.

\section{METHOD}

According to Donaldson and Dunfee (1999), hypernorms can be identified by a conformance of a norm with two criteria of a catalog, posted by these two researchers.

With regard to this theory, the method for the article was developed. In a first step, norms are derived from existing guidelines for companies at the international level. Examples for such guidelines are the 'guidelines for multinational corporations` of the organization for economic cooperation and development (OECD) or the Social Accountability 8000 standard (SA 8000), a standard developed and audited by a civil society organization. Figure 2 shows a compilation of all guidelines used. In the figure the guidelines are divided in those from governmental organizations like the UN or the OECD and in those of non-governmental organizations (NGOs). 


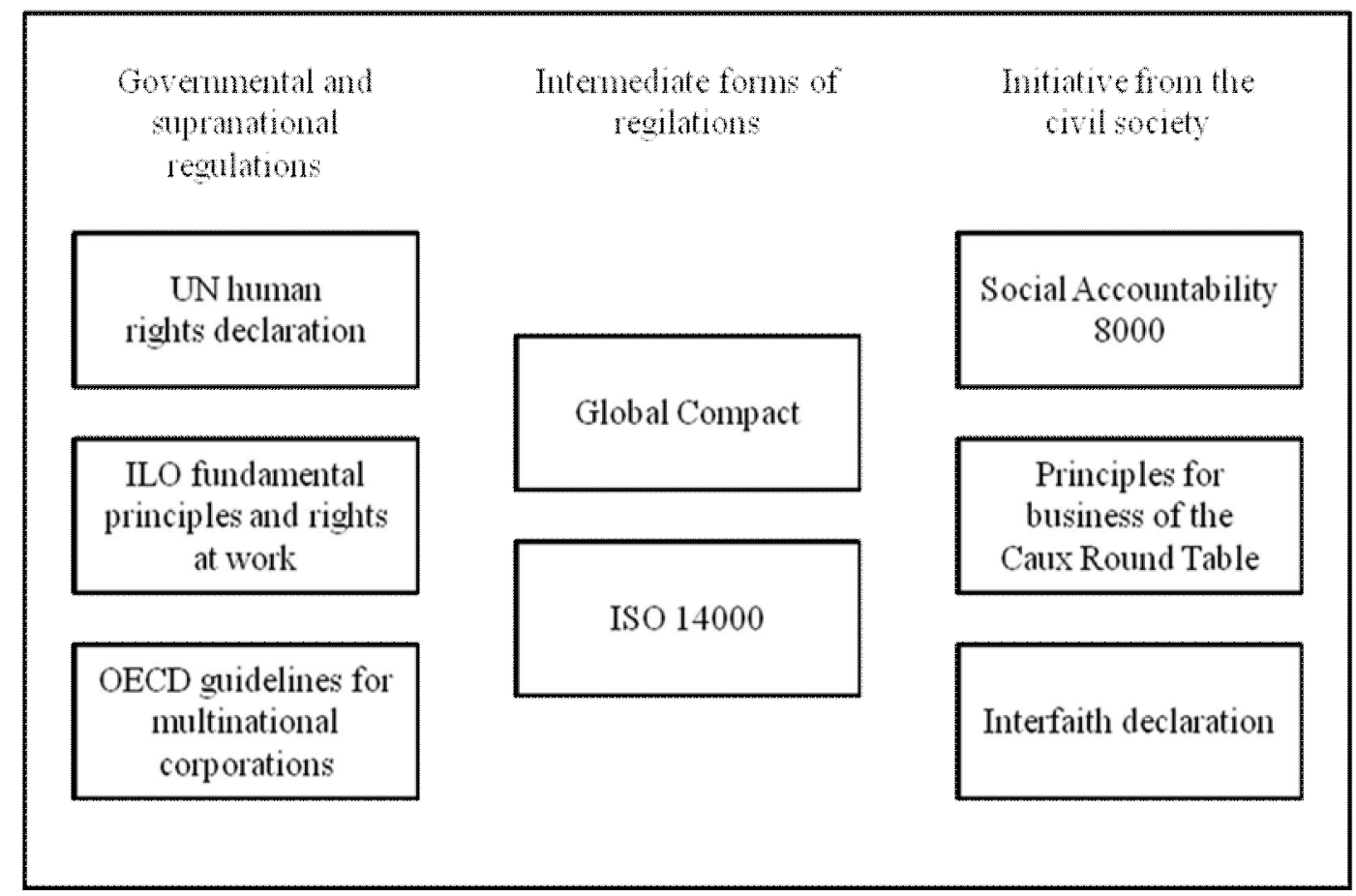

\section{Figure 2: Sources for hypernorms (own drawing)}

In a second step, the evolved provisional catalog of norms is verified by interviews. For this purpose, the method of structured interviews is adopted. The interviews were done with a questionnaire and administrated via phone.

The sample of interview partners is also caused by the theory of Donaldson and Dunfee. The interview partners are from the fields of religion, business and civil society. Overall, 13 persons were interviewed.

The interview partners were informed about each norm and asked about their accordance to the norm. They could evaluate the norms on a scale from one to ten. One in this case means `full rejection` and ten means `full acceptance`.

The results of the interviews were analyzed with Microsoft Excel. The answers are recorded in an Excel-Sheet. A norm was excluded by three categories. First, a norm cannot be a hypernorm if the arithmetic mean is less than eight. Second, a norm cannot be a hypernorm if two of the interview partners point their degree of acceptance with a five or lower or third, if one interview partner points his or her degree of acceptance with three or lower. This acts on the assumption that a low evaluation does not fit with a universal acceptance of a norm.

\section{GLOBALIZATION AND ETHICAL NORMS}

\section{Possible strategies}

In the process of entrepreneurial globalization a company has to make a decision to which ethical norms it would comply (Rothlin, 2006). There is an intercultural challenge because of a discrepancy in the system of ethical norms in different societies, caused by different cultural and religious traditions (Gurbaxani, Frühbauer, 2001).

For determining ethical norms in an international or intercultural context three possible strategies can be distinct, ethnocentrism, relativism and universalism. 
In an ethnocentric view the ethical norms and values of one's own culture or society are superior to those of another culture or society (Messick, Bazerman, 1996). Accordingly, one's own moral conception could be transferred to the other culture without any problems (Schmid, 1996). The ethical norms of one's own culture have an absolute validity in every other culture (Schäfers, 2004). The consequence for a company is that it had to follow the ethical norms of its country of origin. This can cause problems in the host country because the employees of the host country are in conflict with their local ethical norms.

The theory of relativism says that there is no preference for different systems of ethical norms. Two contradictory norms are on the same level and neither of them can be judged as ethically right or wrong (Hofstede, 2006). Because there are no criteria for judging a norm, a company has to follow the norms which are valid in the country the company operates (Beauchamp, Bowie 2001 and Kreikebaum et al. 2001). If local and home country norms conflict, the company should follow the local norms. For a company this can cause problems because of different expectations of the global stakeholders.

In the theory of universalism a system of ethical norms for all humans exists, independent from cultural or religious traditions. Respectively, universalistic norms are autonomous from time and space (Nill, 1994). The validity is not limited by national or cultural borders.

\section{Hypernorms}

The term hypernorm was coined by Donaldson and Dunfee (1994 and 1994). A hypernorm can be defined as a fundamental moral rule for all humans. Hypernorms are reflected in the religious, philosophical and cultural beliefs (Donaldson, Dunfee,1994). They are those norms which are concretized in the respective social and cultural context and become manifested in the community (De George, 2006). The common validity of hypernorms is assumed (Donaldson, Dunfee 1995) and "hypernorms take precedence over the local norms." (Spicer et al., 2004)

Because this research is based on the concept of hypernorms by Donaldson and Dunfee their theory is discussed deeper in this section. Hypernorms play an important role in the 'Integrated Social Contracts Theory' (ISCT). The concept of hypernorms limits relativism. At the same time, hypernorms are not exclusive because they take into account that there can be a difference in the cultural specification. Not every ethical norm can be traced back to a hypernorm and not all existing differences in the system of ethical norms are caused by a different cultural, religious or philosophical imprint (Dunfee, 2006). Therefore, hypernorms are a concept between the conflict of relativism and universalism. "ISCT avoids the extremes of either position by recognizing the dynamic relationships among the authentic ethical norms of diverse communities, bounded in turn by universal principles." (Donaldson, Dunfee, 1999) Those universal principles are called hypernorms which are key limits on moral free space.

In ISCT they distinguish hypernorms in three categories, procedural, structural and substantive hypernorms. Procedural hypernorms are defined as "conditions essential to support consent in microsocial contracts" (Donaldson, Dunfee 1999). Second, structural hypernorms are necessary for political and social organization. They are principles that establish essential background institutions in society. The final category is substantive hypernorms. This substantive hypernorms are fundamental concepts of the right and the good. The substantive hypernorms are those hypernorms that apply to economic activity. (Donaldson, Dunfee, 1999). For this reason, the hypernorms mentioned and developed in this article are substantive hypernorms. Every time when the term hypernorm is used it refers to the definition of substantive hypernorms by Donaldson and Dunfee.

In their book "Ties that bind" Donaldson and Dunfee provide some norms that they have identified as hypernorms. The give examples for international bribery, gender discrimination, market research and workplace safety. The only claim that there are substantive hypernorms concerning those points but they don't provide a formulation of such a hypernorm. 


\section{CORPORATE CODES OF ETHICS}

\section{Definition}

Codes are the most popular measure to institutionalize ethical principals in business (Talaulicar, 2006). A code is a catalog of norms, which are binding standards for human behavior (Kunze, 2008). There are different names for codes of ethics in practice, such as corporate guidelines, business principles or codes of conduct. In this article the term code of ethics is used to summarize all its variable denotations.

The content of a code of ethics are the written business principles, ethical norms and values and rules of conduct of a company. It describes the responsibility for the internal and external stakeholders (Kunze, 2008). This content provides information about which behavior is thought of as ethically right or wrong in a company (Remisova, 2007 and Schwartz, 2004). In every case a code of ethics is a voluntary self-commitment (Kunze, 2008).

Besides corporate codes of ethics there are other codes of ethics in business, such as codes of branches or codes of profession. A code of branch is a self-commitment of a whole branch to follow specific ethical principles. Similarly, a code of profession describes the ethical guidelines of a profession like accountants (Ulrich et al., 1998).

\section{The impact of codes}

A code of ethics is addressed to different stakeholders. It regulates the relationship of a company to its employees, customers or suppliers. Other aspects such as environmental protection can be part of a corporate code of ethics as well (Kaptein, Schwarz, 2008).

If a code of ethics describes the desired behavior of the employees it can considered as a guideline for behavior, which shows the employees what is thought of as ethically right or wrong. This guideline has an impact on the behavior of the employees if they accept the codified norms (Kunze, 2008). A code of ethics coordinates the individual activities in a company. As a result, the behavior of the employees is harmonized by a code of ethics (Talaulicar, 2006). Therefore it is a part of the corporate culture, which also can be a source of information for new employees and help them to integrate into this corporate culture (Kunze, 2008).

A company can signalize its moral responsibility and define the range of the responsibility the company wants to take with a code of ethics (Kaptein, 2004). It is possible to name the ethical areas which seem to be important for the company (Talaulicar, 2006).

In a global context, a code of ethics can help to complete the imperfect framework of regulations. In this context a company can strengthen its credibility and legitimate its activities and so generate trust from its stakeholders (Kreikebaum, 1996). The need to legitimate a company's activities is caused by the multifaceted ways companies are integrated in social communities and institutions and their dependence upon them (Logsdon, Wood, 2002). For this reason, companies strive to keep their social acceptance. Codes and linked ethical programs show the cognition of expectations of the society. Respectively, codes can legitimate the company's activities in a global environment (Weaver et al., 1999).

\section{Challenges for a global corporate code of ethics}

A corporate code of ethics is a part of the corporate culture. If a company wants to act internationally or globally with settlements in foreign countries, a company's own corporate culture will come into contact with the culture of the host country. The challenge at the global level for a code is the possible conflict between the codified norms and the ethical norms of the host country in which the code is transferred (Weaver, 2001). If the code is based on an ethnocentric view the code can cause problems with the employees of the host country. Either they do or do not accept the norms, but they 
have troubles with their conscience because of different cultural norms in their family. The codified norms should not be contradictory to the ethical norms in the host country.

A harmonization of the ethical corporate culture of the head office and the corporate culture of the settlements is possible only to a certain degree. A differentiation with respect to the host country's culture, grounded on a common base of ethical norms, can help to avoid a conflict. On the other side a desired harmonization effect is achievable by the common base, if the base is big enough (Jöstingmeier, 1994). Hypernorms can be a possible opportunity for a common base (Jackson, 1997). In an empirical study Spicer et al. (2004) show, that a hypernorm can be an orientation for managers when they are confronted with ethical decisions.

\section{DEVELOPING HYPERNORMS FOR A CODE OF ETHICS}

Donaldson and Dunfee say that there is evidence for norms to be hypernorms. If two or more of the indicators are fulfilled a hypernorm status is supported. For this purpose they posted the following list with eleven indicators for a hypernorm (Donaldson, Dunfee, 1999).

1. Widespread consensus that the principle is universal.

2. Component of well-known global industry standards.

3. Supported by prominent nongovernmental organizations such as the International Labour Organization or Transparency International.

4. Supported by regional government organizations such as the European Community, The OECD, or the Organization of American States.

5. Consistently referred to as a global ethical standard by international media.

6. Known to be consistent with precepts of major religions.

7. Supported by global business organizations such as the International Chamber of Commerce or the Caux Round Table.

8. Known to be consistent with precepts of major philosophies.

9. Generally supported by a relevant international community of professionals, e.g., accountants or environmental engineers.

10. Known to be consistent with findings concerning universal human values.

11. Supported by the laws of many different countries.

The empirical part is oriented on these indicators. With the study a minimum of two criteria should be fulfilled for each norm.

For this reason, the norms are derived from well-known industry standards (2) like the "SA 8000", standards supported by regional government organizations (4) like the OECD "guidelines for multinational corporations" and standards supported by global business organizations (7) like the Caux Round Tables' "principles for business". Further the UN declaration of human rights is also used because it can be considered as universal (1 and 10).

To review the norms interviews are made with representatives from different religions (6), like Buddhism, Christianity, Hinduism, Islam, Judaism and Confucianism. Further the interviews are done with representatives from non-governmental organizations (NGO), like Transparency International or Amnesty International (3) and with representatives from companies (9).

With the design of the study the requirement to meet two of the criteria can be guaranteed. Figure 3 shows the process of developing a norm with regard to this requirement. 


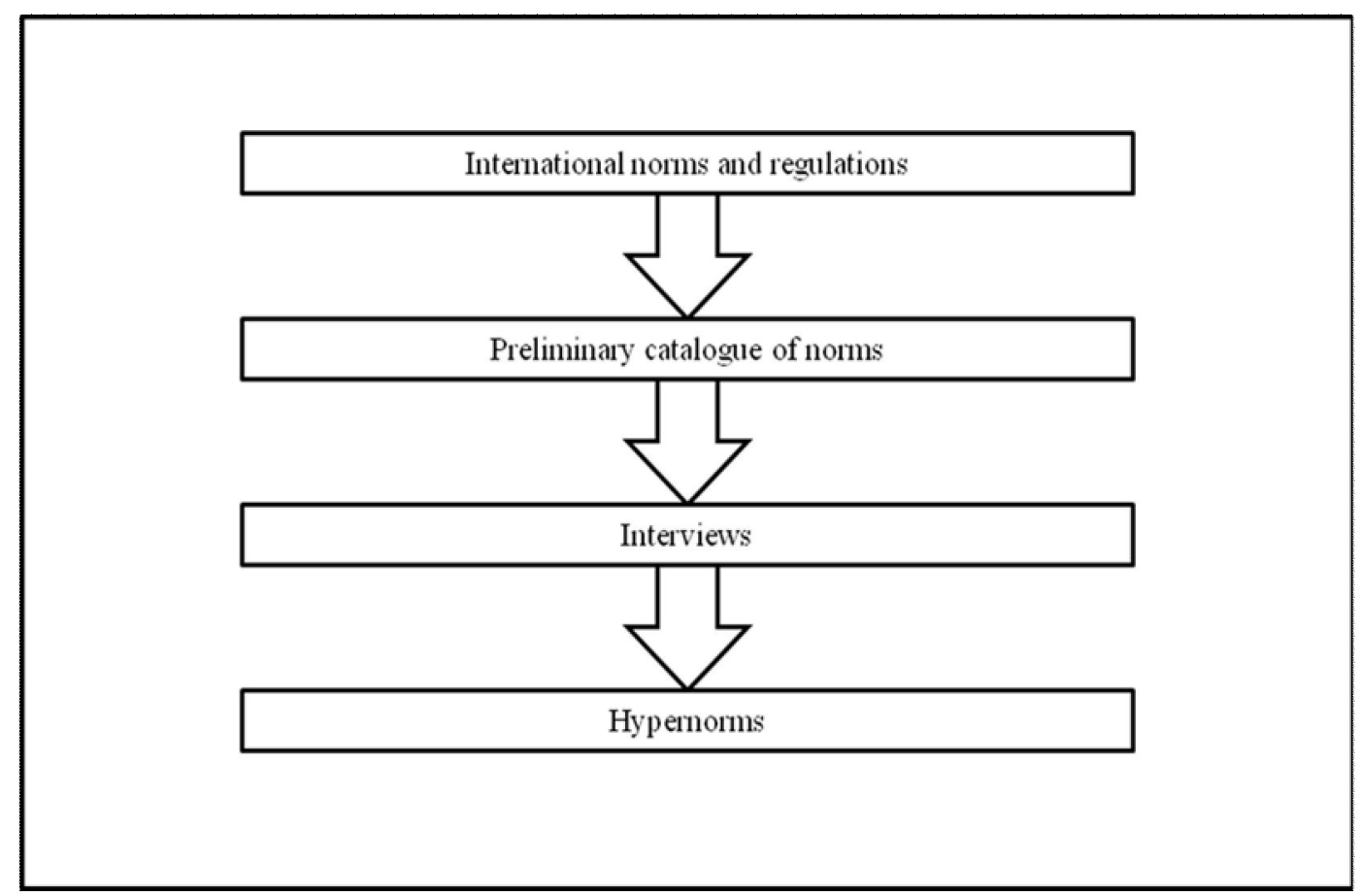

\section{Figure 3: Process of developing a hypernorm (own drawing)}

In a first step a catalogue of norms is derived out of the mentioned sources. This catalogue is proved by interviews with experts in the fields of religion and also with representatives from companies and NGOs. This approach is discussed more deeply in the method-section of this article.

\section{RESULTS}

By deriving norms out of the named standards it was possible to develop a preliminary catalogue of norms. This catalogue consisted of 35 norms. The norms described the responsibilities for the stakeholders of a company. In the first step the norms are separated in the following areas:

1. Responsibility for the employees

2. Responsibility for the costumers

3. Responsibility for the suppliers

4. Responsibility for the environment

5. Responsibility for the society

The reviewing of the norms with interviews leads to an exclusion of some norms. These norms are identified as inconsistent with the principles of religions, standards supported by NGOs or as not practicable for companies. In the end 16 norms could be identified as hypernorms with the definition given in this article. Some of the areas of responsibility are combined because in these areas only one or two norms are left. Following are the norms shown by their area of responsibility.

\section{Responsibility for the employees}

In the first interviews six norms could be developed as hypernorms for business.

1. A company must not put physical or psychological pressure on its employees. This means every type of physical punishment and physical or mental coercion.

2. A company has to provide conditions of work, which are not a danger for the health and security of its employees. 
3. A company has to provide a remuneration, which makes it possible for its employees and their families to cover their basic need of food, clothing, accommodation and health care.

4. A company must not discriminate against its employees on the basis of race, color, gender or religious denomination.

5. A company must not benefit from compulsory labor. Compulsory labor should be defined according to the ILO convention 39.

6. A company has to build a framework which makes it possible for its employees to act ethically, e.g. with a code of conduct.

\section{Responsibility for customers and suppliers}

The areas of responsibility for customers and suppliers are combined because of elimination of norms by interviews in these two areas. For this combined area a set of the following norms could be identified.

1. A company must provide its customers the quality and service agreed.

2. A company must provide all relevant information for the correct use of its products to its customers.

3. A company must commit itself not to conduct fraud or deception regarding the characteristics of its products.

4. A company must pay its suppliers according to the terms of price and date agreed.

\section{Responsibility for environment and society}

The two areas environment and society are combined to one area. In this combined area the following six norms are included.

1. A company has to commit itself to use as few natural resources as possible for its production. On the other side it has to recycle as many resources as possible.

2. A company has to review its business strategic decisions regarding possible environmental risks of its production process, products or services.

3. A company has to review its business strategic decision regarding its effects on the society where the company operates, e.g. plant closure.

4. A company must not be involved in corruption or support corruption by its employees.

5. A company has to make a contribution to the public budget by paying taxes in the country it operates. For this reason it is necessary to know and to comply with the tax laws of the different countries.

6. A company has to respect the intellectual property of other companies or persons.

\section{CONCLUSION}

The introduced hypernorms can be a basis for internationally active companies in developing their own code of ethics. They are a common basis for discussion in designing a code of ethics in an internationally active company. Such a code is the first step for a company to signalize its corporate social responsibility. Amending culturally specific ethical norms in every country is necessary because of the ethical norms that exist beyond the hypernorms. Hypernorms can serve conflicts which are thought to be illegitimate in every country. In situations where an action is thought to be right in one country and wrong in another, hypernorms are not in use. They are just adaptive for culturally universal conflicts. The goal of this research was to develop and to justify hypernorms. It should face critique by Hartmann et al. (2003) or Soule (2002), who have said that the concept of hypernorms presented by Donaldson and Dunfee is too imprecise. The result must be noted differently. One the one hand we can say, that it is possible to develop hypernorms with the aforementioned process. On 
Journal of Global Strategic Management | V. 4 | N. 1 | 2010-June | isma.info| 100-111 | DOI:10.20460/JGSM.2010415843

the other hand is the small sample of interview partners. Because of the small sample there can be no final conclusion as to whether the presented norms are universally valid. This research should give an impulse for further research in the area of norms for international or globally active companies. 


\section{REFERENCES}

Albert H. (1991), Traktat über die kritische Vernunft, UTB, Tübingen.

Aßländer M. S., Brink A. (2008), «Begründung korporativer Verantwortung: Normenkonkretion als Prozess », Scherer, A. G., Patzer, M. (Ed.), Betriebswirtschaftslehre und Unternehmensethik, p. 103 - 124, Gabler, Wiesbaden.

Beauchamp T. L., Bowie Norman E. (2001), Ethical theory and Business, Prentice Hall, Upper Saddle River, N.J.

Boatright J. R. (2007), Ethics and the Conduct of Business, Prentice Hall, Upper Saddle River, N.J..

Chan P. S., Pollard D., Chuo S. (2007), «Corporate Ethics: China vs. USA », International Business \& Economics Research Journal, No. 6, p. $1-8$.

De George, Richard T. (2006), Business Ethics, 6. Ed., Prentice Hall, Upper Saddle River, N.J..

Déniz-Déniz M., Garcia-Falcón, J. M. (2002), « Determinants of the Multinationals’ Social Response: Empirical Application to International Companies Operating in Spain », Journal of Business Ethics, No. 38, p. $339-370$.

Donaldson T., Dunfee T. W. (1994), « Toward a Unified Conception of Business Ethics: Integrative Social Contracts Theory », Academy of Management Review, No. 19, p. $252-284$.

Donaldson, Thomas and Dunfee, Thomas W. (1995), «Integrative Social Contracts Theory », Economics and Philosophy, No. 11, p. $85-111$.

Donaldson T., Dunfee T. W. (1999), Ties That Bind: A Social Contracts Approach to Business Ethics, Harvard Business School Press, Boston.

Dunfee, T. W. (2006), «A Critical Perspective of Integrative Social Contract Theory: Recurring Criticism and Next Generation Research Topics », Journal of Business Ethics, No. 68, p. 303 - 328.

Gurbaxani I., Frühbauer J. (2001), « Globale ethische Standards für globales Wirtschaften: Themen der Baden-Badener Diskussion », Küng H. (Ed.), Globale Unternehmen: globales Ethos: Der globale Markt erfordert neue Standards und eine globale Rahmenordnung, p. 115 - 139, Frankfurter Allgemeine Zeitung Verlagsbereich Buch, Frankfurt a.M..

Hartman, L. P., Shaw, B. and Stevenson, R. (2003), «Exploring the Ethics and Economics of Global Labor Standards: A Challenge to Integrated Social Contract Theory », Business Ethics Quarterly, No. 13 , p. $193-220$.

Hofstede G. (2006), Lokales Denken, globales Denken. Interkulturelle Zusammenarbeit und globales Management, Beck, München.

Jackson K.T. (1997), « Globalizing Corporate Ethics Programs: Perils and Prospects, Journal of Business Ethics », No. 16, p. 1227 - 1235.

Jöstingmeier B. (1994), Zur Unternehmensethik international tätiger Unternehmen, Vandenhoeck und Ruprecht, Göttingen.

Kaptein M. (2004), « Business Codes of Multinational Firms: What do they say? », Journal of Business Ethics, No. 50, p. 13 - 31.

Kaptein M., Schwartz M. S. (2008), «The Effectiveness of Business Codes: A Critical Examination of Existing Studies and the Development of an Integrated Research Model », Journal of Business Ethics, No. 77, $111-127$.

Kreikebaum H. (1996), Grundlagen der Unternehmensethik, Schäffer-Poeschel, Stuttgart. 
Kreikebaum H., Behnam M., Gilbert D. (2001), Management ethischer Konflikte in international tätigen Unternehmen, Gabler, Wiesbaden.

Kunze M. (2008), Unternehmensethik und Wertemanagement in Familien- und Mittelstandsunternehmen: Projektorientierte Analyse, Gestaltung und Integration von Werten und Normen, Gabler, Wiesbaden.

Logsdon J. M., Wood, D. J. (2002), « Business Cititzenship: From Domestic to Global Level of Analysis », Business Ethics Quarterly, No. 12, p. 155 -187.

Messick D. M. and Bazerman, M. H. (1996), «Ethical Leadership and the Psychology of Decision Making », Sloan Management Review, No. 37, p. 9 - 22.

Nill A. F. (1994), «Strategische Unternehmensführung aus ethischer Perspektive », in Bausch T. et al. (Ed.), Ethik und Wirtschaft im Dialog, Lit, Münster.

Remisova A. (2007), « Diversity Management und die Entwicklung der Unternehmensethik in der Praxis », Wagner D., Voigt, B. (Ed.), Diversity Management als Leitbild von Personalpolitik, DUV, Wiesbaden.

Rothlin, S. (2006), « Spannungsfelder der Wirtschaftsethik im chinesischen Kontext », Walacher J., Reder M., Karcher, T. (Ed.), Unternehmensethik im Spannungsfeld der Kulturen und Religionen, p. $40-63$ Kohlhammer, Stuttgart,.

Schäfers, Stefan (2004), Internationale Unternehmensethik: Der Umgang mit moralisch begründeten Forderungen an international operierende Unternehmen, Lit, Münster.

Schlegelmilch, B. B. (1990), « Die Kodifizierung ethischer Grundsätze in europäischen Unternehmen: ein empirische Untersuchung », Die Betriebswirtschaft, No. 50, p. 365 - 374.

Schmid S. (1996), Multikulturalität in der internationalen Unternehmung: Konzepte - Reflexionen Implikationen, Gabler, Wiesbaden.

Schwartz M. S. (2001), « The Nature of the Relationship between Corporate Codes of Ethics and Behavior », Journal of Business Ethics, No. 32, p. 247 - 262.

Schwartz, Mark S. (2004), «Effective Corporate Codes of Ethics: Perceptions of Code Users », Journal of Business Ethics, Vol. 55, 321 - 341.

Soule, E. (2002), « Managerial Moral Strategies: In Search for a Few Good Principals' », Academy of Management Review, No. 27, p. 114 - 124.

Spicer A., Dunfee T. W. and Bailey W. J. (2004), « Does National Context Matter in Ethical Decision Making? An Empirical Test of Integrated Social Contracts Theory », Academy of Management Journal, No. 47, p. $610-620$.

Stehr, C. (2009), « Business Ethics: A possibility to adapt hypernorms in corporate codes of ethics », Adaptive Options, A Global Network of Change and Development, Vol.4/Issue 2, p. 10-16.

Stehr, C. (2010), « Globalisation strategy for small and medium sized enterprises », International Journal of Entrepreneurship and Innovation Management, Special Issue Globalization, Vol.11/No.1, Inderscience 2009 Publishers, Genf.

Stiglitz J. (2006), Chancen der Globalisierung, Siedler, München.

Talaulicar T. (2006), Unternehmenskodizes: Typen und Normierungsstrategien zur Implementierung einer Unternehmensethik, DUV, Wiesbaden. 
Ulrich P., Lunau Y., Weber, T. (1998), « „Ethikmassnahmen“in der Unternehmenspraxis - Zum Stand der Wahrnehmung und Institutionalisierung von Unternehmensethik in deutschen und schweizerischen Firmen: Ergebnisse einer Befragung », Ulrich P., Wieland J. (Eds.): Unternehmensethik in der Praxis: Impulse aus den USA, Deutschland und der Schweiz, p. 121 - 194, Haupt, Bern.

Usrey, K. B. (2007), «Ethics in a Globalized World - What have we Wrought?! », International Business \& Economics Research Journal, No. 6, p. 41 - 48.

Weaver, Gary R. (2001), «Ethics Programs in Global Businesses: Culture's Role in Managing Ethics », Journal of Business Ethics, No. 30, p. 3 - 15.

Weaver G. R., Trevino L. K., Cochran P. L. (1999), « Integrated and Decoupled Corporate Social Performance: Management Commitments, External Preasures and Corporate Ethics Practices », Academy of Management Journal, No. 42, p. 539 - 552.

Winkler I., Remisova A. (2007), « Welche ethischen Problembereiche thematisieren Unternehmen in ihren Ethikkodizes? Ein Vergleich großer westdeutscher und slowakischer Unternehmen », Lang R., Schmidt A. (Eds.), Individuum und Organisation: Neue Trends eines organisationswissenschaftlichen Forschungsfeldes, DUV, Wiesbaden.

Zelizer, V. A. (2007), «Ethics in the Economy », Zeitschrift für Wirtschafts- und Unternehmensethik, Vol. 8. 